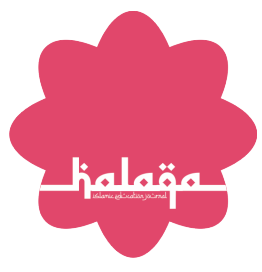

OPEN ACCESS ISSN 2503-5045 (online) ISSN 1412-9302 (print)

Edited by:

Eni Fariyatul Fahyuni

Reviewed by:

Junaidi

${ }^{*}$ Correspondence:

Sadikin Sadikin

Sadikin@upi.edu

Received: 7 Januari 2021 Accepted: 14 Januari 2021 Published: 25 Janurai 2021

Citation:

Sadikin S (2021) The Transformation of MDMC Social Piety in Forming Public Spaces in the Middle of the Covid-19 Pandemic in Indonesia. Halaqa: Islamic Education Journal.

doi: 10.21070/halaqa.v5vi1i.1144

\section{The Transformation of MDMC Social Piety in Forming Public Spaces in the Middle of the Covid-19 Pandemic in Indonesia}

\section{Transformasi Kesalehan Sosial MDMC dalam Pembentukan Ruang Publik di Tengah Pandemi Covid-19 di Indonesia}

\author{
Sadikin Sadikin* \\ Institut Teknologi dan Bisnis-Ahmad Dahlan Jakarta, Indonesia
}

Covid-19 has impacted all sectors of life without exception. In such emergency situations, all elements of civil society, including Muhammadiyah, are required to take part in fighting Covid-19. This study aims to determine the sociological impact of MDMC's social piety transformation on the formation of public spaces in the midst of the Covid-19 pandemic in Indonesia. This research uses descriptive study. By using a qualitative research design, researchers can identify a group of people; study them at home or at work; and develop a general picture of the group, noting how they behave, think and speak. Within the epistemic framework, this research considers several theoretical perspectives on the Covid-19 problem in Indonesia such as grounding the humanitarian movement and caring for Islamic values socially. The results of this study indicate that Muhammadiyah continues to seek solutions to suppress the growth rate of Covid-19 patients in Indonesia. Muhammadiyah continues to convince people to adhere to standard health protocols to cancel the agenda of implementing the congress as a form of Muhammadiyah's concern in saving human lives.

Keywords: Social Piety, MDMC, Public Spaces

Covid-19 telah berdampak pada seluruh sektor kehidupan tanpa tekecuali. Dalam kondisi darurat seperti itu, seluruh elemen civil society, tidak terkecuali Muhammadiyah dituntut untuk mengambil bagian dalam memerangi Covid-19. Penelitian ini bertujuan untuk mengetahui dampak sosiologis dari transformasi kesalehan sosial MDMC terhadap pembentukan ruang publik di tengah pandemi Covid-19 di Indonesia. Penelitian ini menggunakan studi deskriptif. Dengan menggunakan rancangan penelitian kualitatif, para peneliti dapat mengidentifikasi sekelompok orang; mempelajari mereka di rumah atau ditempat kerjannya; dan mengembangkan gambaran umum tentang kelompok itu, mencatat bagaimana mereka berprilaku, berpikir dan berbicara. Dalam kerangka epistemik, penelitian ini mempertimbangkan beberapa perspektif teoritis terhadap persolan Covid-19 di Indonesia seperti membumikan gerakan kemanusiaan dan peduli terhadap nilai-nilai keislaman secara sosial. Hasil penelitian ini menunjukan bahwa Muhammadiyah terus berijti- 
had mencari solusi untuk menekan lajunya pertumbuhan pasien Covid-19 di Indonesia. Muhammadiyah terus meyakinkan umat untuk mematuhi standar protokol kesehatan hingga membatalkan agenda pelaksanaan muktamar sebagai bentuk kepedulian Muhammadiyah dalam menyelamatkan nyawa manusia.

Kata Kunci: Kesalehan Sosial, MDMC, Ruang Publik 


\section{PENDAHULUAN}

Persoalan yang paling fundamental yang dihadapi dunia internasional saat ini adalah kemunculan Covid-19 yang telah melumpuhkan ruang dan keuangan publik. Dilematis berbagai negara dalam memerangi pandemi Covid-19 membuat pemerintah dan seluruh elemen civil society merasakan kecemasan dan kepanikan autentik. Menurut World Health Organization (WHO), total kasus konfirmasi per 27 November 2020 adalah 60.719.579 dengan kasus 1.427.184 kematian, Indonesia berada dipringkat 137 dari 216 negara yang terpapar. Pandemi yang belum pernah terjadi sebelumnya mengakibatkan keadaan global citizenship mengalami kepanikan global. World Health Organization (WHO) mengambil kesimpulan yang cukup radikal untuk meminimalkan statistik Covid-19 dengan melakukan physica social distancing, karantina, dan pembatasan wilayah (lockdown) kendati dapat memperburuk di segala sektor kehidupan. Dampak Covid-19 terhadap pertumbuhan ekonomi di Indonesia, penting untuk dipetakan sejak dini agar dapat terhindar dari jurang resesi di tengah melesuhnya daya beli. Kusno (2020)

Covid-19 telah menjadi bencana global yang melumpuhkan berbagai macam sektor kehidupan tanpa pandang topografi negara, kekuatan ekonomi negara bahkan status negara sebaggai kekuatan ekonomi duniapun tak tebang pilih. Salah satu negara yang jatuh dalam jurang resesi ditengah lonjakan kasus Covid-19 di dunia adalah Singapura. Ekonomi Singupura mengalami kontraksi paling rendah yang pernah dialami. Keadaan itu dipicu oleh kebijakan karantina yang melumpuhkan sektor dagang di negara singa tersebut Pramisti (2020) . Setelah Singapura, satu lagi negara di jajaran ekonomi terkuat di kawasan Asia resmi menyatakan masuk dalam jurang resesi. Negara tersebut adalah Korea Selatan, yang pertama kali dialamainya sejak krisis keuangan tahun 1998. Pandemi Covid-19 memukul perekonomian negara-negara yang selama ini dinilai kuat pertumbuhan ekonominya Jannah (2020) . Filipina menyusul Korea Selatan dan Singapura yang dari awal telah meloncengkan resesi ekonomi dengan kontraksi 0,7\% hingga 16,5\% pada kuartal II 2020. Resesi ekonomi Korea Selatan pada kuartal II mengalami kontraksi 2,9\% ementara Singapura pada kuartal II mengalami kontraksi 12,6\%.

Resesi ekonomi selama pandemi Covid-19 merupakan yang terburuk sepanjang era Great Depression 1930-an. Bank Dunia menyebut musibah global ini sebagai yang terburuk dari Perang Dunia II. Dalam keadaan itu, tak ada ekonomi dunia yang terhindar dari sapuh jagat badai pandemi Covid19. Amerika Serikat dan China sebagai simbol kekuatan ekonomi di dunia mengalami kegoncangan ekonomi. Perbeda nya adalah China selamat dari jurang resesi kendati Covid19 pertama kali ditemukan di sana, sedangkan AS terjebak dalam jurang resesi akibat lengah dalam mengambil sikap preventif. Demikian pula Jepang yang dianggap sebagai negara dengan kekuatan autarki yang cukup tangguh, ikut dihantam badai resesi. Ekonomi Jepang mengalami terkontraksi hingga menyentuh angka 3,4\% akibat menurunnya daya beli masyarakat dan anjloknya ekspor selama pandemi berlangsung. Disamping itu, negara-negara di benua Eropa diprediksikan akan mengalami resesi ekonomi pada kisaran 5,9 persen. Resesi ekonomi menghantui negara-negara di dunia, termasuk Indonesia di tengah andemi Covid-19.

Sementara di Indonesia, total kasus yang telah dikonfirmasi 517.000 dengan kasus 434.000 sembuh dan 16.352 meninggal dunia yang tersebar di 34 provinsi Kesehatan (2020) . Seperti yang telah diprediksikan dari awal, Indonesia akhirnya telah meloncengkan resesi ekonomi pada kuartal III minus 3,49\%. Kondisi ini tak hanya sekadar mendisrupsi perekonomian tetapi juga telah menginterupsi pergerakan ekonomi Kurniawansyah (2020) . Krisis akibat pandemik covid-19 mengharuskan pemerintah mengeluarkan kebijakan pembatasan sosial berskala besar. Kebijakan tersebut diambil dengan harapan dapat menekan kurva Covid-19 yang terus bertambah setiap hari kendati dapat melumpuhkan pertumbuhan ekonomi sebab membatasi aktivitas produksi dan konsumsi di masyarakat.

Kondisi memprihatinkan ini telah berdampak pada semua aspek kehidupan, seperti melemahnya daya beli masyarakat, psikososial masyarakat yang terbelah, daring pendidikan yang tidak efektif, bahkan aspek ritual keagamaan yang harus direvitalisasi dalam upaya untuk menurunkan rantai penyebaran Covid-19. Pandemi Covid-19 yang terjadi di Indonesia menimbulkan banyak kerugian, baik korban jiwa maupun harta benda Suwaryo et al. (2020). Pengurangan risiko bencana dan dampak akibat bencana yang terjadi bisa diminimalisir dengan manajemen bencana yang baik, terutama untuk tahap pra bencana seperti mitigasi dan kesiapsiagaan. Virus corona telah berdampak pada seluruh sektor kehidupan tanpa tekecuali. Salah satu dampak yang cukup signifikan adalah pelaku Usaha Mikro Kecil dan Menengah (UMKM). Dalam kondisi darurat seperti itu, seluruh elemen civil society, tidak terkecuali Muhammadiyah, dituntut untuk mengambil bagian dalam memerangi Covid-19. Unsur-unsur sosial harus bahumembahu dan tidak boleh pasrah serta berpangku tangan dalam menghadapi pandemi ini. Semuanya harus bersatu padu, baik pejabat publik sampai masyarakat di akar rumput sekalipun tak terkucuali harus berperang melawan Covid19 secara berjamaah. Partisipasi ini sangat signifikan dalam melawan Covid-19, karena kunci pokok untuk memutus mata rantai penyebarannya ada pada masyarakat.

Dalam upaya merekonstruksi ruang dan keuangan publik akibat pandemi Covid-19, Muhammadiyah telah menyalurkan donasi sejumlah 450 miliar dalam program-program penanganan Covid-19 (308 milyar pelayanan, 1 milyar penyemprotan disinfektan, 46 milyar pembagian sembako dan 110 milyar beasiswa). Sebagai elemen persyerikatan yang membantu pimpinan Muhammadiyah dalam proses rehabilitasi bencana, Muhammadiyah Disaster Management Center (MDMC) mengambil bagian dalam mitigasi, kesiap siagaan, penanggulangan bencana, rehabilitasi pasca bencana dan juga tanggap darurat. Dalam menjalankan fungsinya dalam proses penanggulangan dan penanggulangan bencana, MDMC selalu 
mengedepankan kode etik kemanusiaan internasional. Hal tersebut dilakukan dalam rangka memperkuat basis ruang publik di tengah pandemi Covid-19 di Indonesia.

Secara sosial, Covid-19 berpotensi menimbulkan konflik yang cukup tajam. Untuk menekan perkembangan statistik Covid-19 dan curva kematian yang terus bertambah, semua elemen bangsa termasuk Muhammadiyah dituntut untuk berperan aktif dalam mengatasinya sebagai bentuk tanggung jawab moral kemanusiaan. Dengan seluruh sumber daya yang dimiliki, Muhammadiyah telah berjuang secara maksimal dengan meminimalkan aktifitas persyerikatan bahkan membatalkan agenda strategis untuk berkontribusi dalam penanganan Covid-19. Dalam ikhtiar memaksimalkan pencegahan, Muhammadiyah mendukung upaya yang telah ditempuh oleh pemerintah dalam upaya memutuskan mata rantai penularan Covid-19 dengan cara pemberlakukan kebijakan social/physical distancing Falahuddin (2020). Dalam upaya mengefektifkan social/physical distancing, guna untuk mencegah lajunya penyebaran virus corona. Pembentukan Muhammadiyah Covid-19 Command C enter (MCCC) merupakan lembaga ad hoc dalam menangani pandemi Covid19 di Indonesia. MCCC telah merekomendasi Rumah Sakit Muhammadiyah dan Aisyiah sebanyak 84 di seluruh Indonesia sebagai tempat rujukan pasien Covid-19. S et al. (2020)

Penelitian mengenai transformasi kesalehan sosial Muhammadiyah Disaster Management Center dalam merekonstruksi ruang publik di tengah pandemi Covid-19 belum disentuh sama sekali. Sebagian besar penelitian hanya fokus pada seputar peran MDMC dalam menangani penanggulangan bencana di Indonesia, pemaparan atau deskripsi saat terjadi bencana, manajemen bencana dan kesiapsiagaan dilakukan setelah mitigasi. Lembaga penanggulangan bencana Muhammadiyah telah diteliti sebelumnya oleh Surahman (2020) mengenai Kualitas Pelayanan Pembinaan Lembaga Penanggulangan Bencana Terhadap Keputusan Satuan Pendidikan Dalam Menggunakan Jasa Konseling Pada Muhammadiyah Disaster Management Center MDMC Surahman (2020) . Hasil penelitiannya hanya melingkupi skala ruang Kabupaten Pamesan. Disamping itu, penelitian ini hanya melihat pelayanan jasa pembinaan penanggulangan bencana dengan mengukur kualitas pelayanan pembinaan penanggulangan bencana tanpa melihat perubahan kualitatif yang ditransformasikan Muhammadiyah Disaster Management Center dalam memperkuat basis ruang publik demokratik.

Kebanyakan penelitian tentang MDMC hanya menggunakan perspektif pendekatan teoritis diakronik bukan dengan kaca mata pendekatan teoritis sinkronik.. Penelitian tentang gerakan MDMC tidak hanya terbatas pada penanggulangan bencana semata, mitigasi, kesiap siagaan, tanggap darurat dan juga rehabilitasi pasca bencana tetapi juga pada nilainilai apa yang ditransformasikan dalam merekonstruksi kembali ruang publik. Permasalahan penelitian terdahulu, kurang mampu dalam mengelaborasi dampak perubahan kualitatif dari gerakan volunter Muhammadiyah Disaster Management Center. Ghozali and Putra (2019); Surahman (2020) hanya mengkaji tentang Peran Muhammadiyah Disaster Management Center Dalam Mitigasi Bencana, namun pada saat yang sama justru menghilangkan dua permasalahan terpenting yaitu dampak perubahan sosial yang terjadi pasca benca, dan pembentukan ruang publik demokratik dari proses transformasi sosial. Dengan demikian, perlu dikaji dengan melakukan studi eksploratif yang lebih dalam dengan menggunakan perspektif sinkronik tentang transformasi kesalehan sosial volunter Muhammadiyah Disaster Management Center dalam merekonstruksi ruang publik di tengah pandemi Covid-19 di Indonensia secara komprehensif.

\section{METODE}

Penelitian ini bertujuan untuk menganalisa proses dan dampak sosiologis dari transformasi kesalehan sosial MDMC dalam pembentukan ruang publik di tengah pandemi Covid-19. Pengambilan data dilakukan secara langsung melaui observasi dan wawancara di lapangan kemudian di evaluasi dengan cara mengkonfirmasi kembali. Penelitian ini dilengkapi dengan menyajikan dan mendeskripsikan faktor-faktor yang mendukung dalam mendeskripsikan penelitian di lapangan. Penelitian ini menggunakan pendekatan kualitatif. pendekatan kualitatif digunakan sebagai alat bantu dalam merumuskan narasi penelitian. penggunaan pendekatan kualitatif disesuaikan dengan masalah yang dihadapi, yaitu dengan harapan dapat memahami masalah-masalah kemanusiaan yang berkenaan dengan transformasi kesalehan sosial muhammadiyah disaster management center dalam merekonstruksi ruang publik di tengah pandemi Covid-19 di Indonesia. Dengan menggunakan pendekatan kualitatif, peneliti dapat mengeksplorasi dan memahami anatomi dari dampak sosiologis dari transformasi kesalehan sosial secara holistik. Bagi Creswell (2015) penggunaan kualitatif dalam metodologi penelitian itu untuk menjawab permasalahan-permasalah yang oleh peneliti tidak mengetahui variabel-variabelnya dan perlu mengeksplorasinya.

Pengelolaan data dari tahap mereduksi, menyajikan, memverifikasi dan menyimpulkan data lebih menekankan pada kajian interpretatif. Bukan dengan perhitungan matematis dan statistik. Creswell (2012) menjelaskan penelitian kualitatif sebagai salah satu penelitian interpretatif. Di mana peneliti membuat suatu penafsiran atas apa yang didengar, dibaca dan dipahami. Dengan demikian, penelitian ini disebut pendekatan naturalistik (Nasution, 2003: hlm, 18). Karena bersifat naturalistik, penelitian tentang kesalehan sosial muhammadiyah disaster management center dalam merekonstruksi ruang publik demokratik di tengah pandemi Covid19 di indonesia, tidak dengan rekayasa, sehingga informasi yang diproleh diharapkan bersifat apa adanya sesuai dengan kejadian yang sebenarnya. Penelitian kualitatif merupakan suatu pendekatan untuk memahami makna yang berasal dari masalah sosial dan kemanusiaan. Studi ini difokuskan pada isu transformasi kesalehan sosial volunter muhammadiyah disas- 
ter management center dalam merekonstruksi ruang publik di tengah pandemi Covid-19 di Indonesia.

\section{HASIL DAN PEMBAHASAN}

Dalam kehidupan sosial, semua manusia adalah sama bila nilai kemanusiaan dimaknai sebagai memanusiakan manusia. Tidak ada alasan apapun untuk melegitimasikan pelecehan atau kerusakan dengan alasan ras, gender, status sosial, topografi dan lingkungan. Nilai kemanusiaan itu sama kendati status sosial cenderung membuat disparitas sosial dalam kehidupan sosial. Dalam hal ini, rasisme adalah bentuk pelanggaran nilai-nilai kemanusiaan universal sebab dasar dari prinsip kemanusiaan adalah setiap manusia mempunyai status yang sama dalam menfungsikan hak dan kewajiban di dalam kehidupan bermasyarakat, berbangsa dan bernegara. Itu sebabnya, tidak boleh ada suku yang merasa lebih antroposentris dari kebudayaan lain.

\section{Konsolidasi Misi Kemanusiaan}

Dalam momentum Hari Kemanusiaan se-Dunia (World Humanitarian Day), MCCC menyelenggarakan konfrensi pers dengan mengusung tema Pahlawan Kehidupan Nyata (real life heroes). Tema peringatan tahun 2020 sengaja dirumuskan untuk dipersembahkan kepada para dokter, perawat, tenaga medis dan para relawan yang telah mendedikasikan hidupnya untuk memerangi tsunami pandemi Covid-19 yang telah gugur dalam melaksanakan tugas kemanusiaan maupun pasien yang terkena wabah pandemi. Peringatan hari Kemanusiaan Sedunia ini, disamping untuk mengingati tragedi kemanusiaan 19 Agustus 2003 di Bagdad sebagai cikal bakal lahirnya hari tragedi kemanusiaan internasional, juga untuk meningkatkan kesadaran kolektif di ruang publik guna untuk mensosialisasikan pengalaman kemanusiaa, mengapresiasi sekaligus menyebarkan inspirasi melalaui pengetahuan tentang nilai-nilai kemanusiaan yang universal.

Atensi MCCC dalam membumikan nilai-nilai kemanusian universal, secara historis telah berawal dari ide kemanusiaan H. M. Syuja, yang disampaikan pada pengajian malam jumat, tepatnya tahun 1917 di Yogyakarta. Berikut ini merupakan ikhtiar yang sudah sedang dilakukan MCCC: a) MCCC menyelenggarakan program edukasi Covid-19 melalui program Siaga Gerakan Hadapi Korona (Sigrak) yang ditopang oleh Depertemen Luar Negeri dan Perdagangan Australia (DFAT) dalam beberapa kegiatan di 13 wilayah dan 34 daerah. Edukasi lainnya yang berkaitan dengan pandemi Covid19 disampaikan melalui kegiatan webiner dengan berbagai macam bidang tema yang meliputi: sosial, budaya, kesehatan, psikologi, ekonomi, kebijakan dan politik. Di samping kegiatan yang bersifat online, Tim Diseminasi dan publikasi MCCC PP Muhammadiyah juga menyampaikan publikasi edukasi bersifat offline; b) Selain publikasi edukasi, MCCC PP Muhammadiyah telah menyelenggarakan call center baik yang berkai- tan dengan isu pandemi Covid-19 maupun layanan konsultasi agama dan psikologi. Publikasi edukasi yang utama dari program MCCC PP Muhammadiyah yang menyangkut inti dari penanganan Covid-19 adalah penerbitan 35 panduan dan tuntutan pencegahan Covid-19 yang didistribusikan pada 13 wilayah dan 34 daerah sasaran program Sigrak.

Komitmen Muhammadiyah terpampang melalui aksi kemanusiaan sejak berdirinya hingga kini. Termasuk komitmen sesama (taawun) selama masa pandemi Covid-19. Melalui MCCC, Muhammadiyah telah banyak melakukan taawun sosial melalui aksi kemanusiaan. Aksi kemanusiaan persyerikatan melintasi paham keagamaan, menyeberangi etnik dan melintasi agama. Dengan cara itu, Muhammadiyah telah mengamalkan nilai-nilai pancasila dalam kekhidupan berbangsa dan bernegara. Muhammadiyah merupakan organisasi keislaman yang membumikan nilai-nilai keislaman dalam konteks pengamalan nilai-nilai pancasila Muhammadiyah (2020). Apa yang telah dilakukan Muhammadiyah melalui MCCC, MDMC, LAZISMU dan RS PKU dalam menghadapi Covid-19 adalah bentuk dari pengamalam nilai-nilai keislaman dalam mengimplementasi pancasila. Kendati Muhammadiyah sudah cukup besar dengan konsep One Muhammadiyah One Respond, agar Majelis, Ortom, Lembaga, dan AUM tidak berjalan sendiri-sendiri, namun perlu membangun relasi yang lebih luas dalam gerakan kemanusiaan. Muhammadiyah tidak akan mempu menyelesaikan semua persoalan-persoalan kemanusiaan dengan sendirian tanpa membangun relasi dengan organisasi lain. Sebab konsep One Muhammadiyah One Respond belum sepenuhnya terintegrasi dengan maksimal dan masih bersifat sektoral. Dengan demikian, dalam upaya membangun gerakan kemanusiaan sebagai revitalisasi gerakan Muhammadiyah yang lebih progresif, perlu adanya kesadaran kolektif dalam membumikan gerakan kemanusiaan bahwa membantu itu penting. Gerakan kemanusiaan yang diproyeksikan MDMC hingga sekarang masih konsisten dan tidak akan bermuarah pada pelayanan profit.

Pembentukan MCCC adalah bagian dari "Jihad Kemanusiaan" Muhammadiyah dalam berperang melawan pandemi Covid-19 di Indonesia. Program MCCC dalam memaksimalkan ruang publik demokratik di tengan lumpuhnya ruang dan keuangan publik adalah memberikan sembako untuk ketahanan pangan, membagikan masker, handsinitazer, penyemprotan disinfektan, membuka layanan konsultasi psikologis secara gratis bagi warga, program pemantauan masyarakat dan warga Muhammadiyah dalam rangka pendataan masyarakat terdampak. Basis logosentrisme Muhammadiyah berkiblat pada hukum agama dan selalu mempertimbangkan ilmu pengetahuan. MCCC dibentuk dalam rangka membantu pemerintah dan rakyat Indonesia pada umumnya. Dalam upaya memaksimalkan ruang publik demokrasi, pemerintahlah yang memiliki kemampuan dan sumber daya yang besar untuk meminimalkan penyebaran wabah Covid19. Karena itu, ledakan curva pasien Covid-19 sangat bergantung pada pola kebijakan pemerintah. Disadari bahwa wabah 
Covid-19 tidak hanya menyerang sendi-sendi biologis manusia namun juga memporak-porandakan seluruh aspek kehidupan masyarakat. Kendati demikian, Muhammadiyah terus berijtihad mencari solusi untuk menekan lajunya pertumbuhan pasien Covid-19 di Indonesia. Muhammadiyah terus meyakinkan umat untuk mematuhi standar protokol kesehatan hingga membatalkan agenda pelaksanaan muktamar sebagai bentuk kepedulian Muhammadiyah dalam menyelamatkan nyawa manusia. Penundaan agenda muktamar hanya semata alasan kemanusiaan, agar tetap fokus dalam penanganan pasien Covid-19 dan sebagai bentuk langkah pencegahan terjadinya gelombang pandemi susulan.

Pembentukan MCCC adalah bagian dari "Jihad Kemanusiaan" Muhammadiyah dalam berperang melawan pandemi Covid-19 di Indonesia. Program MCCC dalam memaksimalkan ruang publik demokratik di tengan lumpuhnya ruang dan keuangan publik adalah memberikan sembako untuk ketahanan pangan, membagikan masker, handsinitazer, penyemprotan disinfektan, membuka layanan konsultasi psikologis secara gratis bagi warga, program pemantauan masyarakat dan warga Muhammadiyah dalam rangka pendataan masyarakat terdampak. Basis logosentrisme Muhammadiyah berkiblat pada hukum agama dan selalu mempertimbangkan ilmu pengetahuan. MCCC dibentuk dalam rangka membantu pemerintah dan rakyat Indonesia pada umumnya. Dalam upaya memaksimalkan ruang publik demokrasi, pemerintahlah yang memiliki kemampuan dan sumber daya yang besar untuk meminimalkan penyebaran wabah Covid19. Karena itu, ledakan curva pasien Covid-19 sangat bergantung pada pola kebijakan pemerintah. Disadari bahwa wabah Covid-19 tidak hanya menyerang sendi-sendi biologis manusia namun juga memporak-porandakan seluruh aspek kehidupan masyarakat. Kendati demikian, Muhammadiyah terus berijtihad mencari solusi untuk menekan lajunya pertumbuhan pasien Covid-19 di Indonesia. Muhammadiyah terus meyakinkan umat untuk mematuhi standar protokol kesehatan hingga membatalkan agenda pelaksanaan muktamar sebagai bentuk kepedulian Muhammadiyah dalam menyelamatkan nyawa manusia. Penundaan agenda muktamar hanya semata alasan kemanusiaan, agar tetap fokus dalam penanganan pasien Covid-19 dan sebagai bentuk langkah pencegahan terjadinya gelombang pandemi susulan.

\section{Kontestasi Misi Kemanusiaan}

Dalam memainkan perannya, gerakan Muhammadiyah sebagai organisasi moderen selalu menyeimbangkan antara orientasi filantropi dan juga orientasi ekonomi. Dua variabel ini merupakan visi kemanusiaan Muhammadiyah dalam memaksimalkan ekonomi umat yang dilandasi dengan sikap saling tolong menolong dalam hal kebaikan. Antar Amal Usaha Muhammadiyah kerap melakukan subsidi silang dalam upaya bekerjasama untuk memajukan umat dan bangsa menuju kemajuan bersama. Pengalaman MDMC dalam misi kemanusiaan sudah berkiprah di dunia internasional den- gan mengikuti berbagai training pelatihan logistik bersertifikat. Dalam merespon realitas kemanusiaan secara komprehensif, Muhammadiyah tidak hanya menyoalkan tentang bencana semata tapi juga kaum rentan, kemiskinan, termasuk difabel. Dalam konsep bantuan, MDMC mulai membenahi bentuk bantuan yang berbasis hak, dengan membuat spesialisasi melalui pelatihan khusus relawan logistik, relawan SAR, relawan layanan medis, dan spesialisasi yang lain. Dalam upaya membangun ruang publik yang demokratis, MDMC telah memberikan bantuan water supply and sanitation. Selain itu ada hunian darurat, pendidikan, layanan psikososial, dapur umum, rekonstruksi, dan logistik.

Melalui MDMC, Muhammadiyah memberikan layanan kepada semua orang tanpa memeriksa latar belakang politik mereka. Muhammadiyah berupayan untuk mewujudkan layanan darurat kebencanaan yang menjangkau seluruh wilayah Indonesia dan bahkan dunia internasional. Gerakan kemanusiaan ini untuk memperluas cakupan gerakan kemanusiaan Muhammadiyah, agar lebih mendunia. Muhammadiyah menjadi satu-satunya lembaga di Indonesia yang memiliki EMT yang diakui oleh WHO. Dalam rangka memperkuat kontestasi kemanusiaan Muhammadiyah di dunia internasional, Majelis Pembina Kesehatan Umum PP Muhammadiyah bersama Lembaga Penanggulangan Bencana PP Muhammadiyah melakukan konsolidasi (recruitment) Tim Kesehatan Bencana/ Emergency Medical Team (EMT) Internasional Muhamamdiyah yang nantinya akan ditugaskan ke lokasi bencana diberbagai penjuru dunia. Perekrutan anggota EMT diambil dari Amal Usaha Muhammadiyah Bidang Kesehatan (AUM-Kes) sedangkan tenaga non medis diambil dari MDMC di tingkat wilayah dan cabang di seluruh Indonesia.

Konsolidasi dan kontestasi MDMC ini disamping sebagai gerakan kemanusian yang universal melampaui batasbatas teritorial, bisa dikatakan juga sebagai respon terhadap berbagai macam konstelasi politik internasional yang cendrung mendiskreditkan nama islam. Berkembangnya islamofobia dan berbagai macam kasus terorisme yang mengatasnakan islam sebagai warga komunitas di dalam berwarga negara. Dengan mengambil sikap inklusif, umat islam menjadi tampilan modernis dari segalah macam jenis agamaagama dunia dan menjadi sentral bagi perkembangan peradaban dunia. Selain sebagai bentuk aksi kemanusian dalam bentuk strategi adaptif dalam menjawab segala bentuk permasalah dunia internasional, Muhammadiyah hadir sebagai ajang pembentukan masyarakat ideal dengan sikap sebagai masyarakat islam yang dapat menjadi jembatan tempat untuk menghubungi antara liberal dan sekuler yang dapat bersikap akomodatif di tengah sentimen di antara keduanya.

Respon lain Muhammadiyah dalam menghadapi perkembangan dunia internasional yang berhubungan dengan globalisasi adalah kesadaran bahwa Muhammadiyah bagian dari global citizenship yang memiliki rasa solidaritas kemanusiaan dan tanggung jawab universal kepada sesama manusia tanpa menyebut perbedaan dan menghitung jarak yang bersifat konvensional dan primordial. Islam berkemajuan dimaknai seba- 
gai islam kosmopolitan yang menjadi ruang untuk berdialog melampaui ruang teritorial. Kiprah Muhammadiyah di dunia internasional di dasarkan pada; Pertama, Muhammadiyah telah menjadi bagian dari global citizenship. Kedua, menginternasionalisasikan gerakan kemanusiaan Muhammadiyah dalam upaya untuk mempromosikan bahwa Muhammadiyah merupakan organisasi kemasyarakatan yang mempunyai peranperan internasional dalam konteks misi kemanusiaan universal. Gerakan ini penting dilakukan mengingat infrastruktur gerakan persyerikatan Muhammadiyah di luar negeri telah dipancangkan di beberapa negara. Gerakan kemanusiaa Muhammadiyah diilhami oleh spirit keberpihakan, spirit pembelaan dan spirit kepeduliaan untuk menolong kesengsaraan umum baik dalam negeri maupun di luar negeri.

Muhammadiyah menilai bahwa Covid-19 bukan rekayasa pihak tertentu, sebab nyaris seluruh negara lumpuh terpapar virus corona. Di samping itu, juga bukan musibah nonalam ataupun kutukan, sehingga membutuhkan ikhtiar dan kekuatan doa agar terhindar dari wabah pandemi tersebut. Bagi mereka yang terkena virus corona agar dapat ditangani dengan semaksimal mungkin guna untuk meminimalkan terjadinya mutasi penyebaran wabah pandemi ini. Dalam menghadapi Covid-19, Muhammadiyah berupaya dalam pencegahan, deteksi dini dan tata pelaksanaan awal dengan mengintrupsikan kepada seluruh elemen amal usaha Muhammadiyah untuk menjadi satu kekuatan masif dan terintegrasi. Program temporer yang dilakukan Muhammadiyah dalam deteksi dini yaitu dengan melakukan safari Covid-19 dan Games Covid19. Safari adalah akronim dari sadar faktor resiko Covid19 sedangkan Games adalah gerakan memberi masker. Gerakan ini berupaya untuk mencegah menularnya Covid-19 dari orang yang positif terjangkit. Untuk menghindari terjadinya ledakan Covid-19 yang maha dasyat, ada dua hal yang harus perhatikan Muhammadiyah, yaitu: Pertama, Muhammadiyah dapat mempersiapkan kesehatan itu sendiri sebagai penan-

\section{REFERENCES}

Creswell, J. W. (2012). Research Design Pendekatan Kualitatif, Kuantitatif, dan Mixed (terjemahan) (Yogyakarta: Pelajar Pustaka), 1-678.

Creswell, J. W. (2015). Riset Pendidikan. Perencanaan, Pelaksanaan, dan Evaluasi Riset Kualitatif \& Kuantitatif (Jogjakarta: Pustaka Pelajar).

Falahuddin, F. (2020). Respons Muhammadiyah Menghadapi Covid-19. MAARIF 15, 137-152. doi: 10.47651/mrf.v15i1.81.

Ghozali, R. P. and Putra, G. (2019). Indoor Positioning System using Regressionbased Fingerprint Method. International Journal of Advanced Computer Science and Applications 10, 33-40. doi: 10.14569/ijacsa.2019.0100829.

Jannah, S. M. (2020). Singapura \& Korsel Resesi, Bagaimana Nasib Ekonomi RI? https://tirto.id/singapura-korsel-resesi-bagaimana-nasib-ekonomi-rifT9z. (Accessed on 2020-09-13).

Kesehatan, K. (2020). Situasi Infeksi Emergency. https://covid19.kemkes. go.id/category/situasi-infeksi-emerging/info-corona-virus/\#.Xvkl85yySyU. (Accessed on 2020-11-27).

Kurniawansyah, H. (2020). Konsep Kebijakan Strategis Dalam Menangani Eksternalitas Ekonomi Dari Covid - 19 Pada Masyarakat Rentan Di Indonesia. Indonesian Journal of Social Sciences and Humanities 1, 130-139.

Kusno, F. (2020). Global political economiy crisis impact of pandemic covid -19. ganan awal. Kedua, public health, yaitu: Muhammadiyah harus memberikan edukasi kepada warga persyerikatan melalui univesitas, sekolah dan amal usaha yang lain untuk membantu melakukan pencegahan sadari dini.

Resistensi menjadi kunci yang harus ditransformasikan dalam program-program MCCC demi menjaga ruang publik dari tsunami pandemi Covid-19. Kendati statistik Covid-19 terus mengalami kenaikan setiap hari dan dapat menimpulkan kelumpuhan ekonomi nasional yang bermuara pada ketahanan pangan warga negara, MCCC bekerja sama dengan Departemen Luar Negeri dan Perdagangan Australia (DFAT) dalam menginisiasi Gerakan Ketahanan Pangan Keluarga (Getapak) dalam mendukung sekaligus mewujudkan ketahanan pangan warga yang terdampak Covid-19. Getapak lebih mengutamakan rumah tangga di perkotaan yang sangat terpukul karena tsunami pandemi Covid-19. Mengutamakan ruang publik di perkotaan tak harus mengabaikan ruang publik di pedasaan. Bagi Muhammadiyah, angka statistik yang dirilis pemerintah setiap hari itu bukan sekedar angka statistik, namun hitungan jiwa manusia yang harus diselamatkan dengan berbagai cara yang harus dioptimalkan.

\section{KESIMPULAN}

Dalam kaitan ini, tugas Muhammadiyah lebih bersifat dakwah dan ikhtiar dalam upaya mencegah penularan Covid-19 yang lebih eksterim. Tidak ada pilihan yang lain selain sikap Muhammadiyah untuk terus berjuang mencegah sebanyak mungkin warga negara dari paparan Covid-19. Kendati kemampuan dan kewenagan Muhammadiyah dalam pencegahan ini masih sangat terbatas. Ketika Muhammadiyah memberikan masukan kepada pemerintah terlepas siapapun yang berkuasa, maka itu adalah bentuk tanggung jawab moral kebangsaan Muhammadiyah yang tulus dan iklas dalam mewujudkan Indonesia Berkemajuan.
Anterior Jurnal 19, 114-122.

Muhammadiyah, S. (2020). Membela Pancasila Membela Kemanusiaan. https://www.suaramuhammadiyah.id/2020/06/22/membela-pancasilamembela-kemanusiaan/. (Accessed on 2020-10-15).

Pramisti, N. Q. (2020). Singapura Resesi Akibat Pandemi COVID-19 Baca selengkapnya di artikel "Singapura Resesi Akibat Pandemi COVID-19. https:// tirto.id/singapura-resesi-akibat-pandemi-covid-19-fQTN. (Accessed on 202009-13).

S, C. I., Napsuparman, and Rusma, R. (2020). Memahami Peran Muhammadiyah dalam Lembaga Non Formal sebagai Islam Gerakan Menghadapi Covid-19 2, 2716-4446.

Surahman, F. (2020). Kualitas Pelayanan Pembinaan Lembaga Penanggulangan Bencana Terhadap Keputusan Satuan Pendidikan Dalam Menggunakan Jasa Konseling Pada Muhammadiyah Disaster Management Center (Mdmc) Kabupaten Pamekasan. Jurnal Konseling Pendidikan Islam 1, 63-76.

Suwaryo, P. A. W., Sarwono, S., and Yuwono, P. (2020). Peran Muhammadiyah Disaster Management Center Dalam Mitigasi Bencana. Jurnal Ilmiah Permas 10, 33-40. doi: https://doi.org/10.32583/pskm.v10i1.663.

Conflict of Interest Statement: The author declare that the research was conducted in the absence of any commercial or financial relationships that could be construed 
as a potential conflict of interest.

Copyright (c) 2021 Sadikin. This is an open-access article distributed under the terms of the Creative Commons Attribution License (CC BY). The use, distribution or repro- duction in other forums is permitted, provided the original author(s) and the copyright owner(s) are credited and that the original publication in this journal is cited, in accordance with accepted academic practice. No use, distribution or reproduction is permitted which does not comply with these terms. 